\title{
Effect of Surface Applied Crude Oil on Soil and Vascular Plant Root Respiration, Soil Cellulase, and Hydrocarbon Hydroxylase at Barrow, Alaska
}

\author{
A. E. LINKINS ${ }^{1}$, R. M. ATLAS ${ }^{2}$ and P. GUSTIN ${ }^{2}$
}

\begin{abstract}
Surface application of crude oil at 5 or $121 / \mathrm{m}^{2}$ to polygonal coastal Arctic tundra altered microbial activity in all soil types during three summers after application. Respiration in $51 / \mathrm{m}^{2}$ oil treated soils increased with decreases in cellulase activity (as endo- and exo-glucanase) and increases in aryl hydrocarbon hydroxylase indicating a shift in the catabolic base of soil microbiota. These trends were paralleled in the $121 / \mathrm{m}^{2}$ soil, but usually after a lag period of one year, perhaps due to some toxic effect of the oil at high concentrations. These data suggest that tundra soil microbiota can actively modify oil and can utilize it to support metabolism. Higher respiration rates in oiled soils than in control soils suggest that soil microbiota degrade and utilize oil faster than the normal residual plant material.
\end{abstract}

\begin{abstract}
RESUME. De brut a été répandu en surface, sur la base de 5 ou 12 litres par mètre carré, sur les sols polygonaux de la toundra de la côte Arctique; ceci altéra l'activité microbienne dans tous les types de sol pendant les 3 étés suivant l'épandage. Dans les sols traités au pétrole, répandu par 5 litres au mètre carré, la respiration s'accroissait puis décroissait dans l'activité cellulaire, (tant pour l'endoglucanase que pour l'exoglucanase); l'hydroxylase des hydrocarbures "aromatiques" s'accroissait en indiquant un changement dans le catabolisme microbien du sol. Ces tendances étaient mises en parallèle avec celles d'un sol traité sur la base de $12 \mathrm{~g} / 1$ mais généralement après un décalage d'un an, peut être dû â quelque effet toxique du pétrole à concentration élevée. Ces expériences suggèrent que le microbiotope du sol de la toundra peut se dégrader activement un utilisant du pétrole dans le sol, à des niveaux plus élevés que celui des hydrates de carbone, leur source normale d'énergie.
\end{abstract}

Traduit par Alain de Vendigies, Aquitaine Co. of Canada Ltd.

\section{INTRODUCTION}

Crude oil applied to the surface of a soil has a significant impact on the soil microbiota and plants as it percolates into the soil. Soil microbiota populations show a rapid increase in response to moderate levels of oil, with a more delayed increase to high levels of oil (Campbell et al., 1973; Dobson and Wilson, 1974; Jobson et al., 1974; Sextone and Atlas, 1977). Much of this population increase is due to increases in oil degrading microflora (Dobson and Wilson, 1964; Jobson et al., 1974; Sextone and Atlas, 1977).,

The effect of oil in the soil on vascular plants has been shown to be quite different. Generally, oil at both moderate and high levels is quite toxic to all higher plants. Shortly after surface application of oil, most plants lose their leaves, show losses in root viability, and die (Deneke et al., 1974; Freedman and Hutchinson, 1976; Linkins and Antibus, 1978; Linkins et al., 1978; Wein and Bliss, 1973). Initial recovery and revegetation have generally been from

'Department of Biology, Virginia Polytechnic Institute and State University, Blacksburg, VA 24061

${ }^{2}$ Department of Biology, University of Louisville, Louisville, KY 40208 
woody plants with protected buds or from vegetative regrowth from surrounding non-oiled soils (Deneke et al., 1974; Linkins et al., 1978; Wein and Bliss, 1973). In general, regrowth in oiled soils is sparce and year to year survival low, especially in Arctic environments.

Even though it is known that microbial populations increase after moderate oil applications and plants generally die or have greatly reduced numbers in oiled soils, little is known about the functional changes in soil microbiota and plant roots in response to oil. It is the purpose of this paper to examine the response of soil microbiota and vascular plant roots in polygonal coastal Arctic tundra to two levels of surface applied oil, 5 and $121 / \mathrm{m}^{2}$. Evaluation will include root-free soil respiration, soil cellulase (B 1, 4 endo- and exo-glucanase), and aryl hydrocarbon [benzo (a) pyrene] hydroxylase, and vascular plant root respiration.

\section{MATERIAL AND METHODS}

Study Sites and Sampling: Study sites were selected in the polygonal coastal tundra at Barrow, Alaska in typical high center and low center polygon complexes (Everett, 1974, 1978). Ambient temperature Prudhoe Bay crude oil was uniformly applied at a $51 / \mathrm{m}^{2}$ or $121 / \mathrm{m}^{2}$ rate on high center polygon centers, and low center rim, trough, and basin systems on 30 June 1975 .

Samples were removed from all plots as a $5.0 \times 6 \mathrm{~cm}$ soil core. Each soil core was immediately placed in a plastic Whirl-pack bag, transported to the laboratory at Barrow, and stored at $2-5{ }^{\circ} \mathrm{C}$ until analyzed. Mid-season samples were taken between 4-12 July each year when soil temperatures and seasonal development were similar (Everett, 1978). Separate subsamples of a core were used for soil respiration, cellulase and aryl hydrocarbon hydroxylase activity, and a separate core was used as a source for roots of the designated plants.

The dominant vascular plant on each plot used for higher plant root respiration were: 1) high center polygon, Lezula confusa Lindeb.; 2) low center polygon rim, Carex aquatilis Wahl.; and 3) low center polygon trough, Dupontia fischeri $\mathrm{R}$. Br. Root respiration studies were not conducted in a low center polygon basin systems due to the sparcity of Carex aquatilis in the particular systems used in this oil spill study (Everett, 1978).

Respiration: All respiration studies were conducted using a Gilson Differential Respirometer. Oxygen and carbon dioxide flux were measured using the direct $\mathrm{KOH}$ method (Umbreit et al., 1964). Respiratory quotients were also determined (White et al., 1973). All flasks were equilibrated at 10 ${ }^{\circ} \mathrm{C}$ before the system was closed and measurements begun. Readings were taken at hourly or half-hourly intervals for 4-6 hrs.

Soil respiration was done on one gram fresh weight samples of soil free of major higher plant root systems. All samples were run in duplicate with final values corrected to a gram soil dry weight basis.

Respiration was monitored on roots gently washed and picked from soil cores taken from the highly vegetated areas of each plot (Billings et al., 1973). Roots were divided into equivalent weight groups for triplicate runs in flasks 
containing $3 \mathrm{ml}$ millipore filtered $(0.45 \mu \mathrm{m}$ pore size) soil water (Linkins et al., 1978). After each run, roots were removed and their dry weights determined. Respiration rates were calculated on a gram dry root weight basis.

Enzyme Assays: Fresh or frozen soil samples with the major vascular root systems removed were used for all enzyme assays. Aliquots of soil were thoroughly mixed at a 5:1 (v/v) sterile soil water, or buffer:soil ratio (Linkins et al., 1978). Assays were conducted at substrate saturating conditions at 25 ${ }^{\circ} \mathrm{C}$ for 4-6 hr.

Cellulase assays included both B 14 endoglucanase and B 14 exoglucanase assays. Endoglucanase hydrolyzes the interior B 14 glycosyl bonds of the cellulose chain while the exoglucanase hydrolyzes B 14 glycosyl bonds near the ends of the cellulose chains releasing soluble short chain oligosaccharides, cellobiose, and glucose.

Endocellulase activity was evaluated by the viscometric method described by Almin and Ericksson $(1967 \mathrm{a}, \mathrm{b})$ in the soil solution as described by Linkins et al., (1978). Exocellulase activity was evaluated from the reducing sugars, in glucose equivalents, released from microcrystaline cellulose incubated in a soil solution (Nelson, 1951; Ross, 1974; Ross and Roberts, 1970; Somogyi, 1944). Glucose oxidase activity was evaluated by the method of Ross (1974).

Aryl hydrocarbon hydroxylase was assayed by a modification of the fluorometric assay with benzo (a) pyrene described by Nebert and Gelboin (1968). Soil samples, with the major vascular plant roots removed, were homogenized in a Waring blender for two full speed $30 \mathrm{sec}$ bursts at $2{ }^{\circ} \mathrm{C}$. The buffer used was a $50 \mathrm{mM}$ phosphate buffer $\mathrm{pH} 6.0$ with $0.36 \mu \mathrm{M} \mathrm{NADPH}^{2}, 3$ $\mu \mathrm{M} \mathrm{MgCl}$ and $100 \mu \mathrm{M}$ benzo (a) pyrene. The reaction was run for $2 \mathrm{hr}$. at 25 ${ }^{\circ} \mathrm{C}$ and stopped by the addition of cold acetone. The mixture was extracted with hexane followed by an alkaline extraction $(1 \mathrm{M} \mathrm{NaOH})$ of the organic phase. Activity is expressed as units of alkali-extractable fluorescence as measured with a Farran A-4 fluorometer (Payne and Penrose, 1975). Control blanks were run in the absence of benzo (a) pyrene.

\section{RESULTS AND DISCUSSION}

Soil Respiration: Table 1 shows the average mid-season values for soil respiration. Control soils show continually declining respiration $(60-91 \%)$ over the three year period. Because mid-season values (15 July 1975, 16 July 1976 , and 12 July 1977) were chosen to minimize the problems of varying temperature, these losses in respiratory activity are presumed to be due to declining soil moisture caused by the 1976-1977 drought conditions in the Barrow area (Everett, 1978). Changes in soil respiration independent of soil moisture but dependent on the presence and amount of oil, can be noted.

During the first year, increases in soil respiration at the 0.05 significance level can be noted in the $51 / \mathrm{m}^{2}$ rim and basin soils, whereas no significant changes occurred in the driest soils, high center, and the wettest, troughs. The 
TABLE 1. Mid-season higher plant root-free soil respiration in $\mu 1 \mathrm{O}_{2} / \mathrm{hr} / \mathrm{g}$ dry wt soil

$\begin{array}{cccc}\begin{array}{c}\text { High Center } \\ \text { Polygon Center }\end{array} & \begin{array}{c}\text { Low Center } \\ \text { Polygon Rim }\end{array} & \begin{array}{c}\text { Low Center } \\ \text { Polygon Trough }\end{array} & \begin{array}{c}\text { Low Center } \\ \text { Polygon Basin }\end{array}\end{array}$

1975

\begin{tabular}{|c|c|c|c|c|}
\hline Control & 138 & 147 & 693 & 197 \\
\hline $5 \mathrm{l} / \mathrm{m}^{2}$ & 161 & 595 & 711 & 360 \\
\hline \multirow[t]{2}{*}{$12 \mathrm{l} / \mathrm{m}^{2}$} & 53 & 72 & 445 & 686 \\
\hline & \multicolumn{4}{|c|}{1976} \\
\hline Control & 71 & 96 & 194 & 269 \\
\hline $51 / \mathrm{m}^{2}$ & 59 & 171 & 473 & 383 \\
\hline $12 \mathrm{l} / \mathrm{m}^{2}$ & 176 & 141 & 397 & 389 \\
\hline
\end{tabular}

1977

\begin{tabular}{lrrrr} 
Control & 31 & 50 & 60 & 40 \\
$51 / \mathrm{m}^{2}$ & 30 & 36 & 238 & 43 \\
$121 / \mathrm{m}^{2}$ & 38 & 37 & 124 & 73 \\
\hline
\end{tabular}

$121 / \mathrm{m}^{2}$ treatments depressed respiration in the two driest systems, high centers and low center rim soils as well as in the wettest trough system. The basin system, however, continued to show increased respiration.

During the second year, all oiled soils except the high center $5 / \mathrm{m}^{2}$ oiled soil showed increases in respiration above the control. Again, the trend of increased respiration paralleling increased soil moisture held, even in this initial year of decreasing soil moisture (Everett, 1978).

In the third year, all systems had abnormally low soil moisture, with the trough system having the least depression from normal levels at the mid-season period (Everett, 1978). Only in the trough system was there any continued elevation in soil respiration. In all other systems, control soil respiration rates were too depressed to permit any meaningful evaluation of the effect of oil independent of the general reduction in soil moisture.

The general effect of oil, then, is initially to stimulate respiration at the 5 $1 / \mathrm{m}^{2}$ treatment levels while depressing respiration at the $121 / \mathrm{m}^{2}$ levels. The second year, however, depression at the $121 / \mathrm{m}^{2}$ levels is absent, perhaps due to reduced levels of some component of crude oil which is toxic at high concentrations or to adaptation of the microbiota to the oil. Complications of low soil moisture content during the third year make precise extrapolations difficult. However, it is evident that oil in the soils does not inhibit overall respiration. In fact, in the trough soils where moisture stress was the least, oil again caused an increase in overall respiration. Whether elevated soil respiration rates continue on a long term basis, presumably due to utilization of oil, is not known, but evidence for the long half life for most of the 
TABLE 2. Mid-season cellulase activity as endo- and exo-cellulase activities

High Center Polygon

Endo Exo

Low Center Polygon Rim

Low Center Polygon Trough

Low Center Polygon Basin

Endo

$\underline{\text { Exo }}$ Endo

Exo

Endo

Exo

\begin{tabular}{|c|c|c|c|c|c|c|c|c|}
\hline Control & $4.1(0.5)$ & $0.4(0.04)$ & $2.6(0.2)$ & $0.4(0.1)$ & $0.3(0.01)$ & $0.1(0.04)$ & $1.5(0.1)$ & $0.4(0.1)$ \\
\hline $51 / \mathrm{m}^{2}$ & $1.2(0.4)$ & $0.01(0.003)$ & $2.1(0.3)$ & $0.07(0.01)$ & $0.3(0.1)$ & $0.03(0.01)$ & $0.01(0.01)$ & $\mathbf{0}$ \\
\hline \multirow[t]{2}{*}{$12 \mathrm{l} / \mathrm{m}^{2}$} & $0.9(0.2)$ & 0 & $0.9(0.2)$ & 0 & $0.1(0.05)$ & 0 & 0 & 0 \\
\hline & \multicolumn{8}{|c|}{1976} \\
\hline Control & $3.0(0.3)$ & $0.4(0.05)$ & $3.0(0.5)$ & $0.3(0.04)$ & $2.0(0.4)$ & $0.4(0.1)$ & $1.0(0.2)$ & $0.8(0.05)$ \\
\hline $51 / \mathrm{m}^{2}$ & $0.24(0.05)$ & $0.02(0.01)$ & $1.4(0.2)$ & $0.1(0.07)$ & $0.9(0.1)$ & $0.1(0.02)$ & $0.5(0.09)$ & $0.6(0.1)$ \\
\hline \multirow[t]{2}{*}{$12 \mathrm{l} / \mathrm{m}^{2}$} & $0.2(0.05)$ & $0.01(0.005)$ & $0.10(0.01)$ & $0.1(0.05)$ & $0.9(0.2)$ & 0 & $0.1(0.01)$ & $0.1(0.04)$ \\
\hline & \multicolumn{8}{|c|}{1977} \\
\hline Control & $2.0(0.6)$ & $0.3(0.05)$ & $0.5(0.1)$ & $0.2(0.04)$ & $2.5(0.4)$ & $0.4(0.05)$ & $0.5(0.5)$ & $0.2(0.04)$ \\
\hline $51 / \mathrm{m}^{2}$ & $0.86(0.2)$ & $0.01(0.004)$ & $0.4(0.05)$ & $0.01(0.003)$ & $0.3(0.03)$ & $0.1(0.04)$ & $0.3(0.05)$ & $0.01(0.01)$ \\
\hline $12 \mathrm{l} / \mathrm{m}^{2}$ & $0.20(0.04)$ & 0 & $0.1(0.01)$ & 0 & 0 & 0 & $\mathbf{0}$ & 0 \\
\hline
\end{tabular}

Endo-cellulase activity expressed as relative bonds hydrolyzed (B)/hr/g dry wt soil; exo-cellulase expressed as glucose equivalents/hr $\mathrm{g}$ dry wt soil corrected for glucose oxidase activity. Standard deviation in parentheses. 
components of crude oil in Arctic tundra (Sextone et al., 1978) suggests a reduction in oil supported respiration may occur with time.

Soil Microbial Enzymes: Root-free soil respiration is a reflection of the metabolic activities of the soil microbiota. These heterotrophs must utilize celluslose in part for their energy in an unperturbed tundra soil and may utilize petroleum hydrocarbon if available. The balance of carbohydrate and/or hydrocarbon utilization can be evaluated most precisely by specific enzyme assays. Cellulase, as both the B 14 endo- and exoglucanase can serve as a model of long term carbohydrate utilization, whereas the enzyme hypothesized to be involved in xenobiotic hydrocarbon metabolism aryl hydrocarbon [benzo (a) pyrene] hydroxylase (Gruger et al., 1977; Ferris et al., 1976; Payne, 1975; Payne and Penrose, 1975) can serve as a model for possible hydrocarbon degradation and utilization.

Table 2 shows B 14 endo- and exoglucanase cellulase activity in root-free tundra soil from the four polygon soils. In control plots, both activities decreased over the three year period, except in the trough systems, again probably a reflection of declining soil moisture (Everett, 1978) and associated oil fungal populations (Miller et al., 1978). Oil, however, significantly depressed all cellulase activity below control values all three years.

The greater relative loss in exoglucanase activity supports the hypothesis that soil microbial populations are not utilizing the hydrolysis products of recalcitrant plant materials, whereas the continued presence of some endoglucanase activity suggests that low numbers of organisms capable of carbohydrate polysaccharide hydrolysis and utilization are still present in the soils. These hypotheses are supported by the declines in fungal populations noted by Miller et al., (1978) which are thought to be the major sources for cellulytic enzymes in soils (Thornton et al., 1975). The increased respiration rates and isolated yeast propagules and bacteria populations (Sextone and Atlas, 1977) in these soils lacking functional cellulase activity give further support to the hypothesis that microbial based degradation and utilization is occurring in oiled soils.

Glucose oxidase, an enzyme involved in the catalysis of glucose to glucuronic acid, contributed to only a $5-10 \%$ loss in glucose during the cellulase incubations. There was only $1 \%$ potential glucose loss by glucose oxidase in oil treated soils.

Aryl hydrocarbon [benzo (a) pyrene] hydroxylase is an enzyme found in mammals, fish, fungi and vascular plant roots exposed to oil or related hydrocarbons (Ferris et al., 1976; Gruger et al., 1977; Linkins, 1978; Nebert and Gelboi, 1968; Payne, 1975; Payne and Penrose, 1975). It is hypothesized, then, that this enzyme may play a role in the zenobiotic hydrocarbon alteration associated with its degradation and metabolism. The presence of AHH activity in homogenized soils could signify such hydrocarbon modification and utilization by soil microbiota. Table 3 shows that AHH activity is present in many of the homogenized oiled soils. In all cases, there is a significant increase in AHH activity in oiled soils above the control soil levels, and these activities generally parallel increased soil respiration over 
TABLE 3. Mid-season aryl hydrocarbon benzo (a) pyrene hydroxylase activity in higher plant root-free soils

$\begin{array}{llll}\text { High Center } & \text { Low Center } & \text { Low Center } & \text { Low Center } \\ \text { Polygon Center } & \text { Polygon Rim } & \text { Polygon Trough } & \text { Polygon Basin }\end{array}$

$\begin{array}{llccl}\text { Control } & 0 & \text { ND } & \text { ND } & 0.2(0.05) \\ 51 / \mathrm{m}^{2} & 0 & \text { ND } & \text { ND } & 0.75(0.10) \\ 121 / \mathrm{m}^{2} & 0 & \text { ND } & \text { ND } & 0.70(0.30) \\ & & & & \\ & & & & \\ \text { Control } & 0 & 0 & 0.04(0.01) & 0.3(0.1) \\ 51 / \mathrm{m}^{2} & 0 & 0.04(0.02) & 0.50(0.05) & 0.95(0.3) \\ 121 / \mathrm{m}^{2} & 0 & 0.04(0.03) & 0.40(0.03) & 0.5(0.1)\end{array}$

$\begin{array}{llccc}\text { Control } & 0 & 0 & 0.01(0.01) & 0.10(0.09) \\ 51 / \mathrm{m}^{2} & 0 & 0.04(0.02) & 0.70(0.09) & 0.35(0.05) \\ 121 / \mathrm{m}^{2} & 0 & 0.07(0.01) & 0.64(0.10) & 0.20(0.07)\end{array}$

Activity expressed as units alkali-extractable fluorescence (Payne and Penrose 1975) /g dry wt soil. Standard deviation in parentheses. ND - Data not taken.

TABLE 4. Mid-season root respiration in $\mu 1 \mathrm{O}_{2} / \mathrm{hr} / \mathrm{g}$ dry $\mathrm{wt}$

\begin{tabular}{ccc} 
High Center & Low Center Rim & Low Center Trough \\
L. confusa & C. Aquatalis & $\underline{D \text { fisherii }}$ \\
\hline
\end{tabular}

$\begin{array}{llrr}\text { Control } & 343(75) & 150(35) & 120(10) \\ 51 / \mathrm{m}^{2} & 165(21) & 67(21) & 60(14) \\ 121 / \mathrm{m}^{2} & 100(17) & 30(10) & 40(10)\end{array}$

$\begin{array}{lcrc}\text { Control } & 560(100) & 220(30) & 110(12) \\ 51 / \mathrm{m}^{2} & 0 & 70(20) & 30(15) \\ 121 / \mathrm{m}^{2} & 0 & 60(17) & 26(9)\end{array}$

$\begin{array}{llll}\text { Control } & 97(10) & 199(26) & 125(21) \\ 5 \mathrm{l} / \mathrm{m}^{2} & 0 & 125(11) & 227(50) \\ 121 / \mathrm{m}^{2} & 0 & 190(60) & 226(45)\end{array}$

Standard deviation given in parentheses. 
the three year period (Table 1) This AHH activity in conjunction with decreasing soil cellulase activity, increasing soil respiration, and increasing isolations of oil degrading bacteria (Sextone and Atlas, 1977) from these soils supports the hypothesis that AHH activity probably is an indirect indication of hydrocarbon degradation and utilization.

The basin and trough non-oiled control soils had AHH activity, and it was these soils which showed the highest AHH levels. This could indicate that there are natural populations of hydrocarbon degraders in these aquatic to semi-aquatic systems which degrade natural hydrocarbons produced by diatoms and blue-green algae.

Vascular Plant Root Respiration: Vascular plant roots form another major biological component of the Arctic tundra. These roots are most important to the Arctic plant because they constitute $80-95 \%$ of the total plant biomass (Dennis and Johnson, 1970; Dennis and Tieszen, 1972; Shaver and Billings, 1975 ). During the winter, the roots/rhizomes constitute nearly $100 \%$ of the revegetation potential for these Arctic plants. $L$. confusa, $C$. aquatilis, and $D$. fischeri all follow this pattern, and Table 4 shows mid-season respiration for their roots from high center and low center rim and trough soils respectively.

Surface applied oil at each level significantly reduced all root respiration in each soil type during the first season. The second season, root respiration of $C$. aquatilis and $D$. fischeri was again depressed. However, respiratory quotients were also depressed from a mean value of $0.9(0.11)$ for control roots to $0.70(0.15)$ for oil treated roots. The third season, respiratory quotients again were lower than controls, $(0.90(0.12)$ for controls; $0.68(0.11)$ for oiled roots), but respiration in the oiled roots was greater than or equal to control roots. This increase in respiration, coupled with lowered respiratory quotients, could indicate a shift in the catabolic base from carbohydrates (RQ $=1.0-0.9)$ to lipid (RQ - 0.66) (White et al., 1973). Demonstration of aryl hydrocarbon [benzo (a) pyrene] hydroxylase in the roots of $D$. fischeri and $C$. aquatilis from long term oil impregnated soils of a natural oil seep supports the interpretation that increased respiration rates coupled with lowered respiratory quotients and $\mathrm{AHH}$ activity may represent some change in the catabolic base in the roots from a carbohydrate base. Whether oil is doing more than just altering metabolism, but actually being utilized must be examined on an enzymological basis.

If increased respiration rates the third year accompanied by an altered respiratory quotient and $\mathrm{AHH}$ activity represent adaptation to oil, then plant root adaptation to oil in the soil is incomplete. This is shown by the annual deceases in viable root biomass after exposure to oil (Table 5). Explanations for this continual loss in viable root biomass have been presented by Antibus and Linkins (1978). Arrhenius plots of respiratory rates and temperature $\left(0.5-26^{\circ} \mathrm{C}\right)$ reveal losses in cold hardiness or tolerance below $5-7{ }^{\circ} \mathrm{C}$ in oil exposed roots. Since soil temperatures below $5-7{ }^{\circ} \mathrm{C}$ are experienced on a 
TABLE 5. Mid-season viable root estimates in soil cores expressed $\mathrm{g} /$ core

\begin{tabular}{lccc} 
& $\begin{array}{c}\text { High Center } \\
\text { L. confusa }\end{array}$ & $\begin{array}{c}\text { Low Center Rim } \\
\text { C. aquatilis }\end{array}$ & $\begin{array}{c}\text { Low Center Trough } \\
\text { D. fisherii }\end{array}$ \\
\hline & & 1975 & \\
Control & & $3.20(0.40)$ & $3.20(0.40)$ \\
$51 / \mathrm{m}^{2}$ & $2.60(0.5)$ & $1.12(0.35)$ & $1.79(0.30)$ \\
$12 \mathrm{l} / \mathrm{m}^{2}$ & $0.90(0.23)$ & $0.73(0.20)$ & $1.95(0.42)$ \\
& $0.48(0.13)$ & 1976 & \\
Control & & $2.70(0.35)$ & $3.75(0.72)$ \\
$5 \mathrm{l} / \mathrm{m}^{2}$ & $2.0(0.2)$ & $1.62(0.20)$ & $1.50(0.60)$ \\
$121 / \mathrm{m}^{2}$ & 0 & $0.80(0.15)$ & $1.40(0.60)$ \\
& 0 & 1977 & \\
Control & & $2.37(0.24)$ & $2.90(0.1)$ \\
$51 / \mathrm{m}^{2}$ & & $0.26(0.09)$ & $0.66(0.30)$ \\
$121 / \mathrm{m}^{2}$ & $1.57(0.5)$ & $0.24(0.10)$ & $0.48(0.15)$ \\
Standard deviation in parentheses. & 0 & & \\
& & &
\end{tabular}

daily basis in mid-summer by these roots (Miller et al., 1974, and unpublished data this laboratory), their ability to grow and support the necessary anabolism would be undermined throughout the entire growing season (Billings et al., 1973).

The effect of oil on the roots of $L$. confusa seems to be greater than on other roots in that there was no viable root biomass at the second or third year. This could be due in part to the increased penetration of oil into the drier high center polygon center soils (Everett, 1978; Sextone and Atlas, 1977) and the very fine nature of the $L$. confusa root system. This latter point is substantiated in that only plants with large roots well protected by a thick epidermis (e. g., Petasites frigida. (L.) Fries., which appeared in low numbers the second and third year after application of oil) survived oil penetration in the high center polygon center soils.

\section{CONCLUSIONS}

Surface application of oil to coastal Arctic tundra causes significant changes in the microbial populations (Sextone and Atlas, 1977; Miller et al., 1978) as well as higher plant root activity (Linkins et al., 1978; Linkins and Antibus, 1978). Changes in microbial activities in response to oil are dependent on the level of exposure. However, the soil microbiota seem to adjust to tolerate and utilize the new carbon source quickly, as is demonstrated by increasing soil respiration, decreasing cellulase, and the presence of aryl hydrocarbon 
hydroxylase in the soil during the season of an early summer oil spill. It is not known if these trends in soil respiration and enzyme activity are indicative of long term microbial activities in tundra soils, as the work of Sextone, et al., (1978) suggests a long retention time for most oil components in these soils.

Higher plant roots do not tolerate or adapt to crude oil in the soil nearly as well as do the microbiota. All roots show depressed respiratory rates for at least a year after initial exposure and show continual declines in viable biomass for three years, despite trends in respiration rates. Although general root respiration increases after two years and indicated altered metabolism, continual decreases in biomass indicate that the roots in the presence of fresh or weathered oil are not able to tolerate such environmental extremes as drought or cold (Linkins and Antibus, 1978; Linkins, et al., 1978). However, stable revegetation in these Arctic environments with oil adapted plants, such as those from the Cape Simpson Oil Seep (Linkins and Antibus, 1978) now seems to be possible.

\section{ACKNOWLEDGEMENTS}

This project was supported by the Department of Energy (ERDA). The authors wish to thank the Naval Arctic Research Laboratory, Barrow, Alaska, for field logistics and support.

\section{REFERENCES}

ALMIN, K. E. and K. E. ERIKSSON. 1967. Enzymatic degradation of polymers I. Viscometric method for determination of enzymatic activity. Biochem. Biophys. Acta 139: 238-242.

- 1967 . Enzymatic degradation of polymers II. Viscometric determination of cellulase activity in absolute terms. Biochem. Biophys, Acta 139: 248-253.

BILLINGS, W. D., G. R. SHAVER and A. W. TRENT. 1973. Temperature effects on growth and respiration of roots and rhizomes in tundra graminoids. p. 57-63. In: L. C. Bliss and F. E. Wielgolaski (eds.) Primary Production and Production Processes, Tundra Biome. Proceedings of the Conference, Dublin, Ireland.

CAMPBELL, W. B., R. W. HARRIS and R. E. BENOIT. 1973. Response of Alaskan tundra microflora to crude oil spills. Proceedings of the Symposium on the Impact of Oil Resources Development on Northern Plant Communities. Institute of Arctic Biology Occassional Publication No. 1. University of Alaska, Fairbanks. pp. 53-62

DENEKE, F. J., B. H. McCOWAN, P. I. COYNE, W. RICKARD and J. BROWN. 1974. USA CRREL research in Alaska, 1970-1974 Corps of Engineers, U. S. Army, Cold Regions Research and Engineering Laboratory, Hanover, NH.

DENNIS, J. G. AND P. L. JOHNSON. 1970. Shoot and rhizome-root standing crops of tundra vegetation at Barrow, Alaska. Arctic Alpine Research. 2:253-266.

- and L. L. TIESZEN. 1972. Seasonal course of dry matter and chlorophyll by species at Barrow, Alaska. p. 16-21. In: S. Bowen (ed.) Proceedings, 1972 U. S. Tundra Biome Symposium.

DOBSON, A. L. and H. A. WILSON. 1964. Respiration studies on soil treated with some hydrocarbons. Soil Science Society America 24: 536-539.

EVERETT, K. R. 1974. Principle soils and geomorphic units of the Barrow sites. U. S. Tundra Biome Data Rep. 74-7.

. 1978. Effects of oil on physical and chemical characteristics of wet tundra soils. Arctic (this volume).

FERRIS, J. P., L. H. MacDONALD, M. A. PATRIE and M. A. MARTIN. 1976. Aryl hydrocarbon hydroxylase activity in the fungus Cunninghamella bainieri: Evidence for the presence of cytochrome P-450. Arch. Biochemistry and Biophysics. 175: 443-452.

FREEDMAN, W. and T. C. HUTCHINSON. 1976. Physical and biological effects of experimental crude oil spills on low Arctic tundra in the vicinity of Tuktoyaktuk, N. W. T., Canada. Canadian Journal Botany. 54: 2219-2230. 
GRUGER. E. H., M. M. WEKELL, P. T. NUMOTO and D. R. CRADDOCK. 1977. Induction of hepatic aryl hydrocarbon hydroxylase in salmon exposed to petroleum dissolved in seawater and to petroleum and polychlorinated biphenyls, separate and together in food. Bulletin Environmental Contamination and Toxicology. 17: 512-520.

JOBSON, A., M. McLAuGhliN, F. D. COOK and W. S. WESTLAKE. 1974. Effects of amendments on the microbial utilization of oil applied to soil. Applied Microbiology. 27: 166-171.

LINKINS, A. E. 1978 (Submitted). Aryl hydrocarbon hydroxylase in mycorrhizal and non-mycorrhizal roots growing in Arctic tundra contaminated with crude oil. Science.

- and R. K. ANTIBUS. 1978. Ectomycorrhizal fungi of Salix rotundifolia II. Impact of surface applied Prudhoe crude oil in mycorrhizal respiration and cold acclimation. Arctic (this volume).

LINKINS, E. E., R. K. ANTIBUS, O. K. MILLER and G. A. LAURSEN. 1978. Impact of crude oil on root respiration and soluble soil cellulase levels in coastal Arctic tundra. S. R. E. L. Mineral Cycling Symposium, Augusta, GA.

MILLER, O. K., G. A. LAURSEN and A. E. LINKINS. 1978. Fungal biomass responses in oil perturbated tundra at Barrow, Alaska. Arctic (this volume).

MILLER, P. C., W. A. STONER and J. EHLERINGER. 1974. Summary of data on some aspects of water relations and microclimate of tundra plants. U.S. Tundra Biome Data Rep. 74-19.

NEBERT, D. W. and H. V. GELBOIN. 1968. Substrate induced microsomal aryl hydrocarbon hydroxylase in mammalian cell culture I. Assay and properties of induced enzyme. Journal of Biological Chemistry. 243: 6242-6249.

NELSON, N. 1951. A photometric adaptation of the Somogyi method for determination of glucose. Journal of Biological Chemistry. 195: 375-380.

PAYNE, J. F. 1975. Field evaluation of benopyrene hydroxylase induction as a monitor for marine petroleum pollution. Science. 191: 945-946.

and W. R. PENROSE. 1975. Induction of aryl hydrocarbon benzo (a) pyrene hydroxylase in fish by petroleum. Bulletin Environmental Contamination and Toxicology. 14: 112-116

ROSS, D. J. 1974. Glucose oxydase activity in soil and its possible interference in assays of cellulase activity. Soil Biology and Biochemistry. 6: 303-306.

- and H. S. ROBERTS. 1970. Enzyme activities and oxygen uptake of soils under pasture in temperature and rainfall sequences. Journal of Soil Science. 21: 368-381.

SEXSTONE, A. and R. M. ATLAS. 1977. Mobility and biodegradability of crude oil in Arctic tundra soils. Developments in Industrial Microbiology. 18: 673-684.

___ and R. M. ATLAS. 1977. Response of microbial populations in Arctic tundra soils to crude oil. Canadian Journal of Micrabiology. 23: 1327-1333.

- , R. M. ATLAS, K. R. EVERETT and T. JENkins. 1978. Fate of Prudhoe Bay crude oil and diesel fuel in tundra soils at Prudhoe Bay and Fish Creek. Arctic (this volume).

SHAVER, G. R, and W. D. BILLINGS. 1975. Root production and root turnover in a wet tundra ecosystem, Barrow, Alaska. Ecology. 56: 401-409.

SOMOGYI, M. 1944. Notes on sugar determination. Journal of Biological Chemistry. 153: 19-23.

THORNTON, J. I., D. CRIM and A. D. MclAREN. 1975. Enzymatic characterization of soil evidence. Joumal of Forensic Science. 20: 674-692.

UMBREIT, W. W., R. H. BURRIS and J. F. STAUfFER. 1964. Mannometric Techniques. Burgess Pub. Co., Minneapolis. 305p.

WEIN, R. W. and L. C. BLISS. 1973. Experimental crude oil spills on Arctic plant communities. Journal of Applied Ecology. 10: 671-682.

WHITE, A., P. HANDLER and E. SMITH. 1973. Principles of Biochemistry, 5th ed. McGraw-Hill Book Co., New York. 1106p. 